\title{
Chemotherapeutic control of trypanosomosis - a review of past measures, current status and future trends
}

\author{
Kingsley I. Eghianruwa*, and Olayinka A. Oridupa \\ Department of Veterinary Physiology, Biochemistry and Pharmacology, University of Ibadan, Nigeria
}

EGHIANRUWA, K. I., O. A. ORIDUPA: Chemotherapeutic control of trypanosomosis - a review of past measures, current status and future trends. Vet. arhiv 88, 245-270, 2018.

\section{ABSTRACT}

African trypanosomosis is a major parasitic disease which affects both humans and animals in the Africa continent, south of the Sahara desert. It is caused by infection with various species of trypanosome that are transmitted to the host through the bite of an infected vector, the tsetse fly. Efforts to control the disease have involved attempts to reduce the vector population by use of traps, insecticide application, the sterile male technique as well as treatment and prophylaxis of overt cases with chemotherapeutic drugs, consisting mainly of isometamidium, homidium, quinapyramine and diminazene. These drugs have been in use for over 50 years and are associated with severe toxicity and parasite resistance. Over the years, efforts in several laboratories to formulate new treatment profiles through pharmacokinetic studies of the trypanocides, combination therapy, use of medicinal plants and application of antioxidants, have not succeeded in eradicating the threat of the disease. The development of an effective vaccine has also not been successful due to the antigenic variation of the trypanosome surface coat, a condition that has stifled progress, if not totally halted vaccine development. However, more recent studies suggest the trypanosomal microtubulin could be a viable antigen for vaccine development. This review focuses on measures that have been undertaken to control Animal African Trypanosomosis by chemotherapy, and discusses future measures and prospects since the measures adopted so far have not successfully controlled the disease.

Key words: chemotherapy; trypanosomosis; control measures; sanative pair; combination therapy; medicinal plants; antigenic variation; tubulin antigen

\section{Introduction}

\section{Preamble}

African trypanosomosis is a disease complex of both humans and animals in the African continent, south of the Sahara. It is caused by infection with various species

\footnotetext{
*Corresponding author:
}

Kingsley I. Eghianruwa, Department of Veterinary Physiology, Biochemistry and Pharmacology, University of Ibadan, Nigeria, Phone: +234 802122 9722; E-mail: keghianruwa@gmail.com 
K. I. Eghianruwa et al.: Chemotherapeutic control of trypanosomosis

- a review of past measures, current status and future trends

of blood and tissue dwelling protozoan parasites of the genus Trypanosoma, that are transmitted by multiple species of the tsetse fly (Glossina spp.) which inhabit about half the non-desert area of Africa. Animal species vary in their susceptibility to the different species of trypanosomes. Cattle, sheep and goats are most commonly infected by $T$. congolense (GROOTENHUIS et al., 1990; SAMDI et al., 2011), T. vivax (WELLDE et al., 1989; KIMETO et al., 1990), and T. brucei brucei (WELLDE et al., 1989). Trypanosoma simiae is the major cause of infection in pigs (ONAH, 1991). Horses are infected by T. equiperdum (SNOW et al., 1996; FAYE et al., 2001), causing a form of the disease called "dourine" which is sexually transmitted. Horses have been observed to be infected by T. congolense, T. b. brucei and T. vivax with an infection rate of $31 \%$ for T. congolense, $87 \%$ for T. vivax and $18 \%$ for T. brucei sp. (SNOW et al., 1996; FAYE et al., 2001; DHOLLANDER et al., 2006; PINCHBECK et al., 2008). Trypanosoma evansi causes surra in a wide variety of wild and domestic animals, including equines, camels, goats, sheep, cattle, buffaloes, pigs, dogs, tigers and elephants (GUTIERREZ et al., 2008; RATHORE et al., 2016). Trypanosoma evansi is mechanically transmitted by bloodsucking flies, such as Tabanus and Stomoxys species, and its ability to infect human beings has been reported (RATHORE et al., 2016). Chickens are naturally resistant to the disease (JOSHUA, 1982). In humans, T. brucei rhodesiense is responsible for an acute form of trypanosomosis in Eastern and Southern Africa (FEVRE et al., 2005), while T. b. gambiense causes a chronic form in West and Central Africa (SMITH et al., 1998; MAUDLIN, 2006). Sporadic reports have appeared of other trypanosome species causing the disease in humans. These include T. congolense (TRUC et al., 1998) and T. evansi (JOSHI et al., 2005; WABALE et al., 2015; CHAU et al., 2016). Trypanosoma barrettoi has been isolated from the blood of fish (LOPES et al., 1990). Animal reservoirs play an important role in the epidemiology of both animal and human trypanosomosis (NJOKOU et al., 2006; SIMO et al., 2006). Wild animals can also suffer from trypanosomosis, although they generally have greater tolerance to the disease than domestic animals.

Animal African trypanosomosis has been a major constraint to agricultural production in about 10 million $\mathrm{Km}^{2}$ of sub-Saharan Africa (LUCKINS, 1992; ILRI, 1996). Over 40 million head of Africa's cattle population are kept in tsetse infested areas (BUDD, 1999). Cattle living in areas where trypanosomosis is endemic are $20 \%$ less productive in terms of meat and milk production than herds living in tsetse and trypanosomosis-free areas (BUDD, 1999). It has been estimated that direct losses due to trypanosomosis, in the areas of meat, milk, traction power, and control programs, amount to US\$ 500 million and indirect losses resulting from the inability to keep livestock and grow food because of poor human health, amount to US\$ 5 billion per annum (ILRI, 1997).

Concerted efforts to control trypanosomosis have been going on over the past century (DREWS, 2004). Numerous methods of control have been developed, yet the disease has 


\section{K. I. Eghianruwa et al.: Chemotherapeutic control of trypanosomosis}

- a review of past measures, current status and future trends

proved very difficult to eradicate. Ironically, trypanosomes were among the first organisms to be targeted by synthetic drugs. Paul Ehrlich, 'the father of chemotherapy', chose these organisms as a model on which to test his ideas (DREWS, 2004). Chemotherapy has been a major component in the control of trypanosomosis but no new trypanocide has been introduced into the field since the early 1960s (ONYIAH, 1997). This is partly because of the prohibitive cost of discovering, developing and introducing new drugs onto the market (GEERTS et al., 2001; LINARES et al., 2006). For instance, in 1975, the $\$ 1$ billion spent on drug research and development in the USA yielded only seven drug entities, in sharp contrast to the situation in the 1950s in which about forty new drug entities were introduced yearly, with a total annual research and expenditure of less than \$100 million (TROUILLER and OLLIARO, 1999). This situation is partly due to the scope of testing required by the regulatory bodies, with the consequent increase in expenditure. The huge capital required by the developed economies to develop new trypanocides is regarded as hardly worth it because the political and economic situations in the countries where trypanocides are required are not encouraging (MURGOLO et al., 1989; GEERTS et al., 2001). Human African trypanosomiasis (HAT) has thus been classified as a neglected disease (REMME et al., 2002). BARRETT et al., (2007) define neglected diseases as those ailments which affect people from among the world's poorest populations, for which satisfactory treatment does not exist, but for which the investment required to bring new compounds to the market has proven a major disincentive to drug development.

\section{Chemotherapy of trypanosomosis}

Chemotherapy and chemoprophylaxis of animal trypanosomosis rely on the use of trypanocidal drugs. They are the mainstay of trypanosomosis control measures (ONYIAH, 1997; BARRETT et al., 2007) and will probably remain so for a long time, in spite of the problems of drug resistance and toxicity (ROSS and TAYLOR, 1990; GEERTS et al., 2001; BALDISSERA et al., 2016a) because drugs are the only method of control readily available to individual farmers.

The drugs currently in use in animal trypanosomosis include: diminazene aceturate $\left(\right.$ Berenil $\left.^{\circledR}\right)$, isometamidium chloride $\left(\right.$ Samorin $\left.^{\circledR}\right)$, homidium chloride $\left(\right.$ Novidium $\left.^{\circledR}\right)$, homidium bromide $\left(\right.$ Ethidium $^{\circledR}$ ), quinapyramine methylsulfate (Antrycide ${ }^{\circledR}$ ), and quinapyramine methylsulfate/chloride (Antrycide prosalt ${ }^{\circledR}$ ). Of these, only Berenil and Samorin are commonly available. Berenil is used exclusively as a therapeutic agent, while Samorin has both prophylactic and curative properties. Homidium has limited prophylactic properties. Table 1 shows the list of drugs that have been used in the treatment of Animal African Trypanosomosis (AAT). These trypanocides have been in use for over 50 years. Today, 
K. I. Eghianruwa et al.: Chemotherapeutic control of trypanosomosis - a review of past measures, current status and future trends

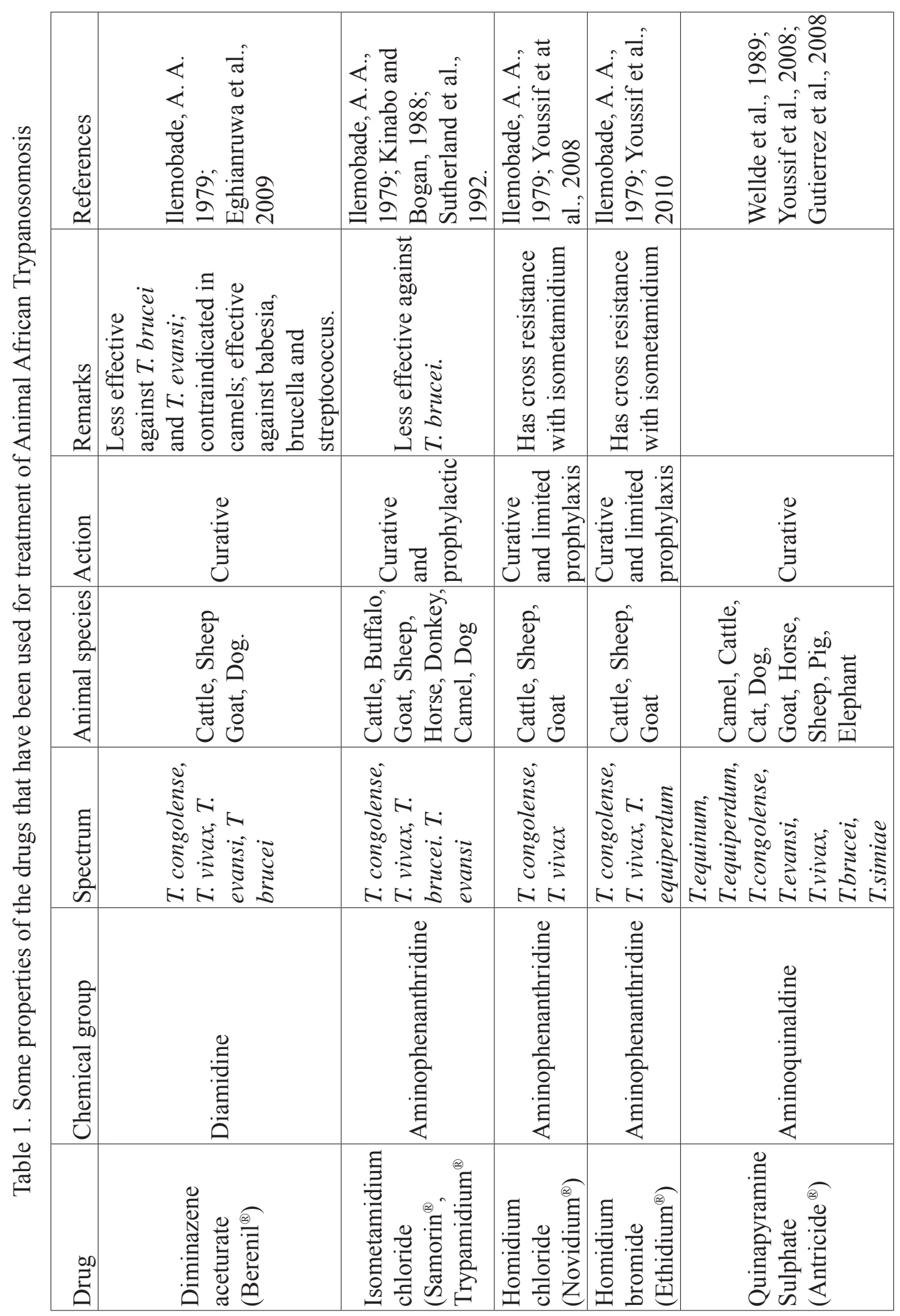


K. I. Eghianruwa et al.: Chemotherapeutic control of trypanosomosis - a review of past measures, current status and future trends

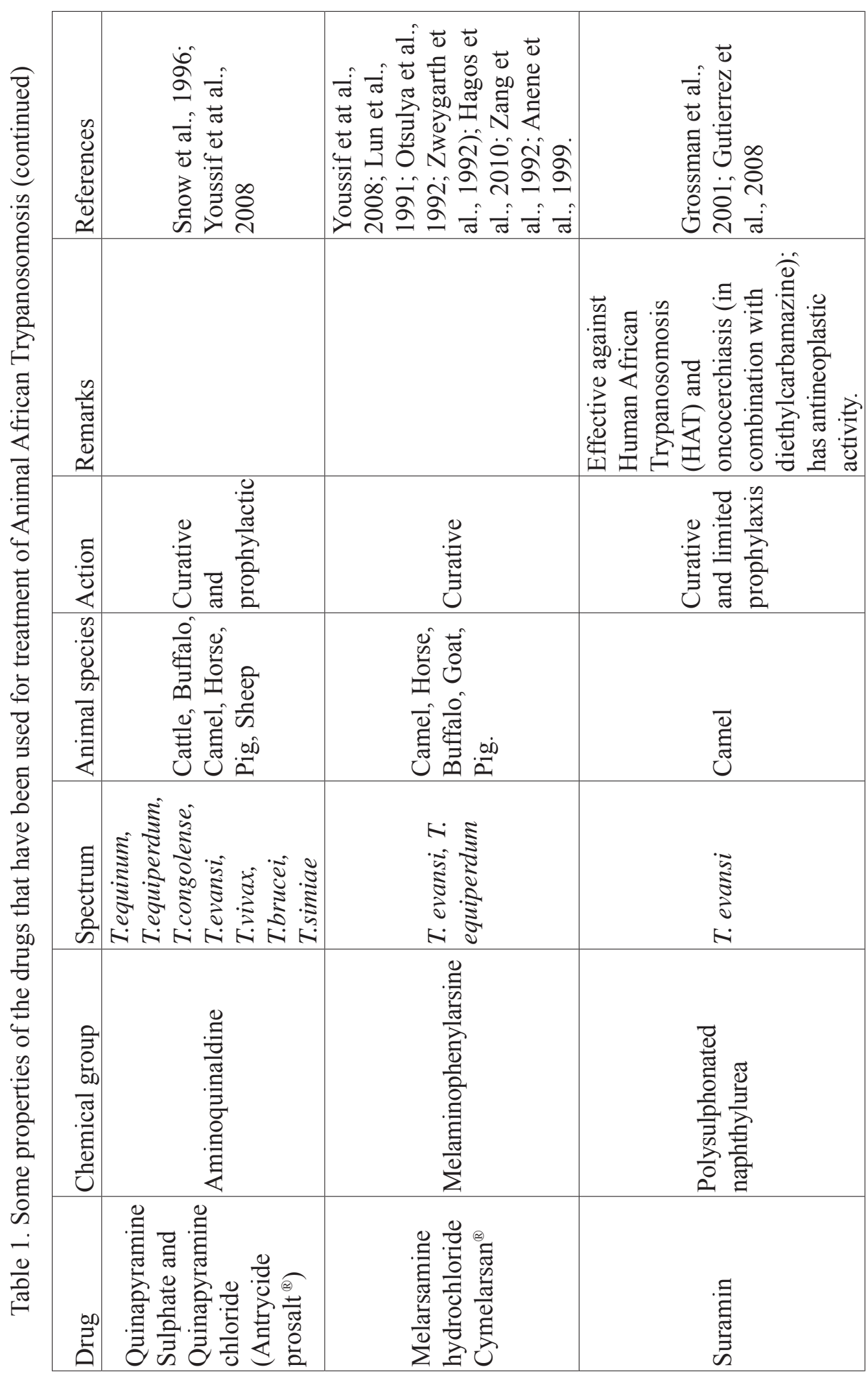

Vet. arhiv 88 (2), 245-270, 2018 
K. I. Eghianruwa et al.: Chemotherapeutic control of trypanosomosis

- a review of past measures, current status and future trends

parasite resistance to these drugs is widely reported (AFEWERK et al., 2000; ANENE et al., 2001; KAGIRA and MAINA, 2007; SHIFERAW et al., 2015).

A relatively new, water-soluble trivalent arsenical agent, melarsamine hydrochloride, has been evaluated as a trypanocide. Melarsamine hydrochloride is a melaminophenylarsine compound made by conjugation of one equivalent of melarsen oxide and two equivalents of cysteamine. It was patented in 1985 under the trade name Cymelarsan (Rhone Merieux, France). It has been shown to be very effective against T. brucei brucei, T. evansi, and T. equiperdum in camels, buffalo, goats, and pigs (LUN et al., 1991; OTSULYA et al., 1992; ZWEYGARTH et al., 1992). YOUSSIF et al. (2008) reported that cymelarsan was effective at a single dose of $0.25-0.625 \mathrm{mg} / \mathrm{kg}$ in Nubian goats infected with $T$. evansi. The authors also observed that the single dosage of $1.25 \mathrm{mg} / \mathrm{kg}$ and the multiple dosages were toxic and fatal, and that the drug has an accumulative effect. Cymelarsan was also found to be effective against diminazene aceturate-resistant T. brucei brucei and T. evansi (ZHANG et al., 1992). ANENE et al. (1999) evaluated the efficacy of Cymelarsan, against $T$. brucei infection in mice and dogs, and observed improvements in their clinical condition as well as weight gains in treated dogs. On the basis of the results from the evaluation experiments, MelCy was licensed for use against trypanosomosis in animals. Recently, HAGOS et al. (2010) also found Cymelarsan to be quite effective in curing horses with the acute as well as the chronic form of dourine.

\section{Attempts at improving the efficacy of trypanocidal drugs}

In the absence of new drugs, it was deemed necessary by several researchers to formulate new treatment protocols to improve the efficacy of the existing drugs. The goals have been to elucidate the pharmacokinetics of trypanocides; formulate an inexpensive, non-toxic, easy to administer chemotherapeutic drug, or to create a medium that would enhance the efficacy of the existing trypanocides. Some of the foci of research included:

Pharmacokinetic studies on available trypanocides to improve our understanding and enable a reassessment of the dosages and treatment protocol.

Complexation of trypanocides with adjuvants.

The use of a sanative pair.

The use of hyperosmolar agents to enhance drug distribution and penetration into the brain.

The use of combination therapy involving trypanocides, antioxidants and natural products.

\section{Pharmacokinetic studies}

In line with the objective of a better understanding of the pharmacokinetics of trypanocides, and reassessment of dosages and treatment protocols, the pharmacokinetic profile of diminazene aceturate (DMA) was intensively studied in several animal 
K. I. Eghianruwa et al.: Chemotherapeutic control of trypanosomosis

- a review of past measures, current status and future trends

species, including rabbits (GILBERT, 1983), monkeys (RAETHER et al., 1974), cattle (MAMMAN et al., 1993; ALIU et al., 1993), dogs (ONYEYILI and ANIKA, 1989, 1991), goats (ALIU et al., 1984; ONYEYILI et al., 2002), sheep (ALIU and ǾDEGAARD, 1985), and rats (ODIKA et al., 1995). Absorption of diminazene aceturate through the oral route has been recorded in some animal species, including rats (RAETHER et al., 1974; KELLNER et al., 1985) and monkeys (RAETHER et al., 1974).

It was observed that DMA $(3.5 \mathrm{mg} / \mathrm{kg})$ administered intravenously to mongrel dogs after infection with $T$. congolense was rapidly distributed in the body. However, the infection had no marked influence on the urinary excretion of the drug, whereas intravenous administration of DMA $3.5 \mathrm{mg} / \mathrm{kg}$ in $T$. b. brucei infected mongrel dogs significantly altered the kinetic disposition of DMA (ONYEYILI and ANIKA, 1989). The distribution half-life of the drug was markedly decreased and there was a prolonged elimination half-life, with a decreased total body clearance in the infected animals. These observations were attributed to the pathological changes in the cardiovascular system induced by trypanosomal infection. The tissue distribution and residue profile of DMA $(3.5 \mathrm{mg} / \mathrm{kg})$ was also investigated in healthy dogs, and in dogs infected with T. congolense and T. b. brucei treated intramuscularly (ONYEYILI and ANIKA, 1991). Diminazene was observed to be distributed to various organs and tissues of the body, with the highest concentrations occurring in the liver and kidneys. Higher drug levels were found in the tissues of healthy dogs when compared with those of trypanosome infected animals, except in the brain. Drug residues were still detectable in the tissues of the animals 10 days after drug administration (ONYEYILI and ANIKA, 1991).

In another study, the effect of chlorpromazine (CPZ) on the tissue distribution of DMA was also investigated in rabbits. There was a delay in the attainment of peak concentration in the rabbits treated with DMA $(7 \mathrm{mg} / \mathrm{kg}$, intramuscular) and CPZ $(5 \mathrm{mg} / \mathrm{kg}$, intramuscular). High levels of DMA occurred in the brain of rabbits given a combination of CPZ and DMA compared to the level obtained in the rabbits given DMA alone. This indicates the greater penetration of DMA into the central nervous system of the rabbits that received a combination of CPZ and DMA (ONYEYILI et al., 1992).

With regards to isometamidium (ISMD), BRAIDE and EGHIANRUWA (1980) reported that drug levels were detected in goat plasma 24 hours after intramuscular injection, but not after intravenous injection. These authors attributed this observation to its rapid distribution from the systemic circulation. ISMD concentrations were also detected in appreciable levels in the liver and kidneys, 12 weeks after intravenous administration. No drug concentration was detected in the muscles, except at the intramuscular site of injection. The authors attributed the prophylactic action of the drug to this intramuscular depot, which becomes limited following encapsulation resulting from local tissue reaction (ALIU and CHINEME, 1980). As a result of the known tissue reaction of ISMD 
K. I. Eghianruwa et al.: Chemotherapeutic control of trypanosomosis

- a review of past measures, current status and future trends

at the intramuscular site of injection, OGUN and EGHIANRUWA, (1993) evaluated the absorption rate of ISMD from the stomach and intestine of rats, and reported that ISMD was appreciably absorbed from the stomach and not from the intestine. In a comparative efficacy study of ISMD following intramuscular and oral administrations, the intramuscular route was found to be clearly superior (EGHIANRUWA et al., 2004).

\section{Complexation of trypanocides}

Complexes of ISMD with adjuvants have also been produced to alter the kinetic profile of ISMD. Studies involving the Isometamidium-dextran complex and isometamidiumsuramin complex were undertaken in the late seventies and early eighties (JAMES, 1978; ALIU and SANNUSI, 1979; ALIU and CHINEME, 1980), following the suggestion that complexation would alter the kinetics of absorption and lengthen the prophylactic period. The results of the studies showed that the amount of isometamidium-dextran complex containing an equivalent of the therapeutic dose of uncomplexed drug extended the period of effective prophylaxis by several months in both rats and mice (JAMES 1978). Following studies on the isometamidium-dextran complex, ALIU and SANNUSI, (1979) concluded that the complex, at a 1 or $2 \mathrm{mg} / \mathrm{kg}$ subcutaneous injection, could be expected to protect cattle against trypanosomosis and still yield good carcass and hide grading. The therapeutic index of the isometamidium-dextran complex was four times that of isometamidium alone (ALIU and CHINEME (1980). The subcutaneous site of injection of the complex tolerated a higher dose of isometamidium, with a resultant increase in the prophylactic period (ALIU and SANNUSI, 1979; ALIU and CHINEME, 1980).

FLUCK and HOPKINS (1988), incorporated Diminazene, homidium and isometamidium into liposomal formulations, with a view to prolonging their activity and improving tolerance. The authors observed no adverse effects after administration of the phospholipid complexes as multilamellar liposomes, but reported that the reaction at the intramuscular injection site to liposomal isometamidium was markedly less than the reaction to a isometamidium solution, even though the liposomal preparations did not substantially enhance the duration of the prophylaxis of the three compounds.

\section{The use of a sanative pair}

This concept, which was first suggested by WHITESIDE (1962), prescribes the sequential use of a pair of chemically unrelated trypanocides (e.g. Berenil and Homidium). The concept entails the use of one of the sanative pair until resistant strains of trypanosomes appear, following which the second is substituted and used until the resistant strains have disappeared from cattle and tsetse. A modified version of this concept ultimately became the trypanosomosis drug policy of the then Northern Region of Nigeria. The drug policy prescribed that each of the two curative drugs be used for six months of the year when a species of trypanosomes sensitive to the drug was predominant (ILEMOBADE, 1979). 
K. I. Eghianruwa et al.: Chemotherapeutic control of trypanosomosis

- a review of past measures, current status and future trends

For example, T. vivax was found to be generally susceptible to homidium compounds and was the predominant species in cattle when they were withdrawn to the wet-season grazing areas; whereas T. congolense was generally susceptible to berenil and was the predominant species in cattle during the dry season when cattle were moved to pastureland in the tsetse belts of the south. However, this treatment regime was rather short lived, as isolates of $T$. congolense and $T$. vivax with multiple resistance to curative trypanocides were isolated and subsequently found to be widespread.

\section{Hyperosmolar agents and relapse infections}

Poor drug distribution to infected tissues, particularly the brain, is one of the host related factors associated with relapse of trypanosomosis infection (JENNINGS et al., 1979). Diminazene aceturate, the routine drug for treating trypanosomosis in Nigeria, has small molecular size but its charged nature prevents easy passage across the blood-brainbarrier (BBB), with the result that in cerebral trypanosomosis, the trypanosomes evade its trypanocidal action. In order to overcome this failure to reach the required therapeutic concentrations at the parasite location in the brain, hyperosmolar agents such as lithium chloride $(\mathrm{LiCl})$ and sucrose were used in combination with trypanocides, to achieve the osmotic opening of the BBB and the resultant effective chemotherapy. Lithium chloride and sucrose are known to effectively open the BBB (SPATZ et al., 1976).

Intramuscular lithium chloride $(10 \mathrm{mg} / \mathrm{kg})$ caused a significant increase in the brain concentration of DMA $(3.1 \mathrm{mg} / \mathrm{kg} \mathrm{im})$. The addition of sucrose $(1.0 \mathrm{~g} / \mathrm{kg} \mathrm{im})$ was not as effective. The DMA levels were also significantly higher in the organs (brains, kidney, liver and spleen) of trypanosome infected rats compared to those uninfected (ODIKA et al., 1995). Furthermore the concentration of DMA in the organs increased significantly $(\mathrm{P}<0.05)$ with increasing concentrations of LiCl (ODIKA et al., 1995).

\section{Combination therapy}

It has been suggested that the low efficacy of trypanocides may result from under-dosing, poor drug quality, rapid-infection with short-acting therapeutic agents (such as DMA) and drug resistance. To exclude the possibilities of under-dosing and poor drug quality, samples of DMA and isomethamedium chloride obtained locally were analyzed, and the results showed that the qualities were of acceptable standards. This result thus suggested the existence of genuine drug resistance in the field (ANENE et al., 1996).

In order to address the problem of drug resistance, a study was conducted in vitro to assess the ability of calcium antagonists of several chemical classes (verapamil, cyproheptadine, desipramine and chlorpromazine) to reverse resistance of Trypanosoma evansi to a range of trypanocides including DMA, suramin and MelCy. The putative resistance modulators were intrinsically antitrypanosomal, but were unable to reverse resistance to any of the trypanocides tested (ANENE et al., 1996). 
K. I. Eghianruwa et al.: Chemotherapeutic control of trypanosomosis

- a review of past measures, current status and future trends

Again, because most of the available trypanocides in use were developed over 5 decades ago, it was perceived that their long usage and misuse may have encouraged the development of drug resistant parasites. A study was thus conducted to assess the efficacy of Difluoromethylornithine (DFMO, eflornithine), a newly introduced human trypanocide in the treatment of both primary and relapse infections of Trypanosoma brucei in dogs. Simultaneous administration of DFMO intravenously and single dose of diminazene $(7 \mathrm{mg} / \mathrm{kg})$ in primary infections achieved a higher chemotherapeutic level compared to the monotherapy, as no relapses occurred (ANENE et al., 1997).

The suggestions of some authors (IGBOKWE, et al., 1998; UMAR et al., 2000; IHEDIOHA and ANWA, 2002) of the possible involvement of Reactive Oxygen Species (ROS) in the pathogenesis of trypanosomosis prompted the evaluation of the efficacy of diminazene aceturate alone and in combinations with antioxidants (ascorbic acid, dimethyl sulfoxide, tocopherol and selenium) in experimental murine T. brucei and $T$. congolense infections. Results from these studies were variable, with both the species of trypanosome and antioxidants. When considered in totality, antioxidant supplementation following diminazene injection showed superiority over diminazene alone in reversing the pathological conditions caused by trypanosome infection (EGHIANRUWA et al., 2009, EGHIANRUWA and ANIKA, 2010, 2011, 2012; EGHIANRUWA and OBIDIKE, 2011; EGHIANRUWA, 2012).

An overview of the many efforts made to obtain better therapeutic results from drug treatment of overt trypanosomosis cases showed that these treatments relieved the animals temporarily of the parasitaemia. No treatment protocol had the desired prolonged and lasting effect. Moreover, the issue of relapse and drug resistance could not be resolved.

\section{Future trends in the chemotherapy of trypanosomosis Development of new drugs}

One of the most significant problems faced in controlling the spread of trypanosomosis is that there is little economic incentive to conduct research in these impoverished parts of the world that are endemic to the disease, and it is difficult to get expensive drugs to the people. The drug discovery scenario, however, is changing dramatically. Several potential drug targets and molecules have been recognized.

One of the drug targets identified so far is related to an unusual enzyme, Trypanosome Alternative Oxidase (TAO) which T. brucei uses in glycolysis. This enzyme is the terminal oxidase of the respiratory chain of long slender bloodstream forms of the African trypanosome, and it is absent from the host (NIHEI et al., 2002; CHAUDHURI et al., 2006). The amino acid sequence of TAO in HAT-causing trypanosomes was observed to be identical to that in non-human infective T. b. brucei (NAKAMURA et al., 2010). As an essential factor for trypanosome survival, TAO is a promising drug target in both 
K. I. Eghianruwa et al.: Chemotherapeutic control of trypanosomosis

- a review of past measures, current status and future trends

human and animal Africa trypanosomes, due to the absence of alternative oxidases in the mammalian host. Ascofuranone, a compound isolated from the phytopathogenic fungus Ascochyta visiae, has been shown to be the most potent inhibitor of TAO to date (NIHEI et al., 2002). NAKAMURA et al. 2010 reported that ascofuranone, quickly kills trypanosomes in vitro and cures mice infected with T. b. brucei. The potential of Cathepsin (CATL), a lysosomal cysteine peptidase, as an important potential drug target in trypanosomes has also been suggested (ALSFORD et al., 2014).

KALIDAS and PHILIPS (2012) reported systematic analysis of approximately 200 genes coding for enzymes involved in different biochemical and signaling pathways, by RNA interference (RNAi) knockdown or gene knockout. RNA interference is a phenomenon through which double stranded RNA (dsRNA) induces potent sequencespecific degradation of homologous transcripts, and it has emerged as an invaluable tool for elucidation of gene function and drug target validation (VINCENT et al., 2008). Using a newly developed vector (pTrypRNAiGate), KALIDAS and PHILIPS 2012, have knocked down seven aminoacyl tRNA synthetases (AARS), which have an important role in protein translation. RNAi against five AARS resulted in growth inhibition of the T. brucei bloodstream forms in vitro.

It is well established that the bloodstream forms of trypanosomes in a patient have a coat of variant surface glycoprotein (VSG) that shields them from the immune system (TAYLOR and RUDENKO, 2006). However, the procyclic forms, which are the first life-cycle stage to develop in the tsetse fly, replace the VSG coat by procyclins that do not protect the parasite from lysis by serum components. This process of differentiation from bloodstream to procyclic forms is specific to the parasite and has been exploited by some workers to screen for potential drug candidates (WENZLER et al., 2016).

The prospects for exploiting differences between parasite and mammalian protein kinases to develop new trypanocides have been reported (NAULA et al., 2005). Protein kinase regulates many different cellular processes, such as transcriptional control, cell cycle progression and differentiation (WIESE et al., 2003; ELLIS et al., 2004) and its potential as drug targets is not restricted to trypanosomosis but also to a wide range of diseases and syndromes, such as cancer, cardiovascular disease and Alzheimer's disease (SEBOLT-LEOPOLD and HERRARA, 2004; NAULA et al., 2005; STRUMBERG and SEEBER, 2005).

Some researchers have suggested that one approach to finding new drugs and rediscovering old ones is based on enzyme inhibitors that paralyze antioxidant systems, which are essential to the parasites as they are attacked in the host by reactive oxygen species, such as peroxynitrite, hypochlorite, and $\mathrm{H}_{2} \mathrm{O}_{2}$ (KRAUTH-SIEGEL et al., 2005). The antioxidant system of the trypanosome is thought to consist of some 20 thiol and dithiol proteins centered around the unique dithiol trypanothione. Several workers have 
K. I. Eghianruwa et al.: Chemotherapeutic control of trypanosomosis

- a review of past measures, current status and future trends

considered this antioxidant system as a potential drug target in trypanosomes (BUDDE and FLOHE, 2003; KRAUTH-SIEGEL et al., 2005; JAEGER and FLOHE, 2006). Evidence from gene disruption studies indicates that trypanothione and other low molecular mass thiols are directly or indirectly maintained in a reduced state by trypanothione reductase, an apparently essential enzyme, which appears to be unique to this genus (KRIEGER et al., 2000; BEIG et al., 2015). Blocking the synthesis of trypanothione could be a useful pathway for developing a drug which would kill the parasites without harming the human host. KRIEGER et al. (2000), reported that trypanosomes lacking trypanothione reductase are avirulent and show increased sensitivity to oxidative stress. Competitive and irreversible inhibitors of the enzyme have been designed, and some have been tested following attempts to exploit trypanothione reductase as a chemotherapeutic target (STEENKAMP, 2002; STUMP et al., 2007; RICHARDSON et al., 2009; BELLUTI et al., 2014).

Evidence from literature indicates that significant advances are being made in the search for new drugs, especially against Human Africa Trypanosomosis. Further studies will be required to ascertain the activities of these new drugs in treating Animal Africa Trypanosomosis.

\section{Improved drug delivery to target sites in the parasite}

Drug resistance and the low therapeutic index of available trypanocides have been some of the limiting factors to the effective control of trypanosomosis by chemotherapy (DELESPAUX and De KONING, 2007). One mechanism by which trypanosomes develop resistance is by alteration of the nucleoside transporter system associated with the movement of drug molecules to target sites within the parasite (SHIFERAW et al., 2015). Resistant populations of trypanosomes are known to take and accumulate less trypanocides than sensitive ones (SUTHERLAND et al., 1992; MULUGETA et al., 1997). While the search for new drugs is ongoing, efforts to develop new drug formulations, that would improve drug delivery to target sites within the parasite with consequent increases in efficacy and safety, are equally being pursued. Studies are ongoing in several laboratories on the application of nanotechnology in the development of drug delivery systems to treat parasitic diseases. Nanoparticle based drug delivery systems possess the advantage of improved efficiency, arising from their ability to deliver the drug to the required target. Efficient drug delivery is also associated with reduced toxicity, prolonged drug effect, improved stability of therapeutic agents and reduction in drug dose (SINGH and LILLARD, 2009). The benefit of nanoparticle-coupled drugs in drug targeting has been realized in cancer therapy, where such drugs act specifically on the cancer cells (De JONG and BORM, 2008). Some reports are available on the advantages of nanoparticle-coupled drugs in trypanosomosis. UNCITI-BROCETA et al. (2015) using nanoparticles of chitosan loaded with pentamidine and coated by a 
K. I. Eghianruwa et al.: Chemotherapeutic control of trypanosomosis

- a review of past measures, current status and future trends

single domain nanobody that specifically targets the surface of African trypanosomes, and have reported a 100 fold reduction in curative dose compared to pentamidine alone. These authors also reported that pentamidine loaded onto chitosan was active against a trypanosome cell line known to be resistant to pentamidine, due to mutations in the surface transporter. The higher efficacy of the chitosan-pentamidine formulation was associated with improved entry of pentamidine into trypanosomes through endocytosis, instead of via the classical cell surface transporters (UNCITI-BROCETA et al., 2015). The nanoparticle delivery system has also been extended to natural products, such as nerolidol, that possess antitrypanosomal actions. Nerolidol is an aliphatic sesquiterpene alcohol present in the essential oils of many plants with proven in vitro activity against T. evansi (MOHD-SHUKRI and ZAINAL-ABIDIN, 2011; BALDISSERA et al., 2016b). Orally administered nerolidol-loaded nanosphere in T. evansi infected rats resulted in a survival rate of $66.66 \%$ compared to $0 \%$ when nerolidol was used alone, or $33.33 \%$ survival rate obtained with diminazene (BALDISSERRA et al., 2016b). Studies on nanoparticle drug delivery systems have witnessed vigorous activity and expectations are high. If the results obtained from pentamidine-loaded nanoparticles can be replicated in other aged trypanocides, the technology may well lead to the resurgence of the old drugs.

\section{Medicinal plants and natural products as potential sources of trypanocidal drugs}

It is a truth universally acknowledged that plants are important sources of medicines. Plants do not only contain active pharmacological principles, but their contents are also used as template molecules for the production of new drugs. Hence, the knowledge gained from the use of medicinal herbs and their active ingredients has served as the foundation for much of modern pharmacology, and many modern drugs have their origin in ethnopharmacology. Patronage of traditional based medical systems, in which higher plants constitute the main sources of drug therapy, has increased steadily over the past decade. Novel treatment strategies for the management of several disease conditions, such as diabetes and many forms of cancer, have emanated from herbal medicines (GURIBFAKIM and MAHOMOODALLY, 2013).

There is an abundance of reports in the literature from studies, both in vivo and in vitro, which have been conducted to investigate the effectiveness of traditionally used medicinal plants in alleviating the effect of trypanosomosis on the host (SALEM and WERBOVETZ, 2006; MANN and OGBADOYI, 2012). HOET et al. (2004), reviewed 120 plant derived compounds, consisting of alkaloids, phenolic derivatives, quinones, terpenes and other metabolites, which reportedly possess activity against African trypanosomes (mainly Trypanosoma brucei subsp., T. congolense and T. vivax) in a submicromolar range, out of which 12 were shown to be relatively selective. Chemical modification of natural products, such as ascididemin, neocryptolepine, tryptanthrin and diospyrin, resulted in more trypanosomal activities and less toxicity, again illustrating how natural products can 
K. I. Eghianruwa et al.: Chemotherapeutic control of trypanosomosis

- a review of past measures, current status and future trends

serve as a basis for developing derivatives with increased activity and/or lower toxicity (HOET et al., 2004).

Few natural products have been evaluated in rodent models of African trypanosomiasis. Some encouraging reports have been published (ASUZU and CHINEME, 1990; AKANJI et al., 2009; OMOJA et al., 2011; MANN and OGBADOYI, 2012). Ascofuranone, a prenylated phenol antibiotic and a structural analog of coenzyme $\mathrm{Q}$ isolated from a phytopathogenic fungus, Ascochyta visiae, resulted in 100\% cure of mice infected with T. b. brucei when given by intraperitoneal route in combination with glycerol. The compound was reported to be highly non-toxic in vivo and able to cross the blood-brain barrier (MINAGAWA et al., 1997; YABU et al., 2003, 2006). Similarly, a fraction of the oily extract from garlic bulbs cured mice infected with T. b. brucei in four days, when given intraperitoneally at a dose of $120 \mathrm{mg} \mathrm{kg}^{-1}$ per day (NOK et al., 1996).

Thorough understanding of the mode of action of the pharmacologically active principles in natural products is still lacking. However, possible mechanisms have been suggested in some cases. For instance, NOK et al. (1996), attributed the action of the oily extract from garlic bulbs to its interference with the parasites' synthesis of membrane lipids. Similarly, the mechanism of the action of ascofuranone, a structural analog of coenzyme $\mathrm{Q}$, is attributed to its binding at the coenzyme $\mathrm{Q}$ site of ubiquinol oxidase, thus blocking trypanosome alternative oxidase (TAO), one of the two enzymes associated with a unique mitochondrial electron transport system in T. $b$. brucei bloodstream forms. Glycerol suppresses the second enzyme, glycerol-3-phosphate dehydrogenase, by mass action. Hence, it has been observed that inhibitors of TAO become trypanocidal when combined with glycerol, due to the total block of the energy production of bloodstream forms (NIHEI et al., 2002).

The gap in the complete knowledge of these promising antitrypanosomal natural products can be bridged by in-depth interdisciplinary investigations to elucidate their actions and identify new leads. The ultimate benefit for trypanosome endemic areas would be to design inexpensive standardized medicines, following validation and identification of the active principles in the plants used in traditional medicine to treat African trypanosomosis.

\section{Vaccine production}

Success has not been forthcoming in the production of vaccines against trypanosomosis. Studies have shown that bloodstream forms of trypanosomes circumvent the host immune response by continuous changes to surface glycoprotein, hence continuous changes in antigenicity. The variable surface glycoproteins (VSGs) are antigenically distinct due to extensive differences in the primary sequences (TAYLOR and RUDENKO, 2006; RUDENKO, 2011). Antigenic variation of the parasite has been seen as one of the 
K. I. Eghianruwa et al.: Chemotherapeutic control of trypanosomosis

- a review of past measures, current status and future trends

most spectacular adaptive mechanisms exhibited by the African trypanosomes, and the main reason why the development of vaccine has been elusive (MURRAY et al, 1979). The trypanosome has therefore been credited as the ultimate immune destroyer and escape artist (La GRECA and MAGEZ, 2011). A review of the various attempts made to vaccinate both domestic livestock and laboratory animals showed from the reported studies that complete protection was readily achieved only if the same variable antigen type (VAT) was used for immunization and challenge (GRAY, 1976; MURRAY et al., 1979; TABEL et al., 2008). When a distant VAT was used for challenge, no protection occurred. Following these observations, many researchers in the area of trypanosomosis control have assumed that an effective vaccine would have to contain all VATS, possibly an insurmountable task as the number of VATS is likely to be large. Hence many consider the possibility of vaccination to be remote.

Although this view has been widely held and propagated, some workers have shown that failure to achieve effective vaccination to control trypanosomosis is due to factors other than antigenic variation (WEI and TABEL, 2008; WEI et al., 2011; TABEL et al., 2013). Studies have shown that antibodies to the VSG are required for the control of African trypanosomes infecting the blood, whereas infections of the skin by low numbers of trypanosomes are controlled by innate resistance and do not require antibodies for their control. Low numbers of trypanosomes infecting the skin, although killed by innate resistance, do not induce protection, but enhance susceptibility to re-infections due to suppression of the innate resistance by adaptive immune responses (MANSFIELD and PAULNOCK, 2005; WEI and TABEL, 2008; WEI et al., 2011; TABEL et al., 2013). These workers concluded that immune suppression, which is one of the cardinal effects of Trypanosomosis, is responsible for vaccine failure. DARJI et al. (1992) proposed that immune suppression is attributed to the coexistence of at least two unlinked suppressive mechanisms that block different T-cell regulatory steps and operate through different effector mechanisms, and the authors linked these mechanisms to the generation of prostaglandin-producing macrophages which are entirely responsible for the suppression of IL-2 production, whereas the induction of a prostaglandin-independent suppressive mechanism accounts for the suppression of the expression of IL-2 receptors (IL2R). This point of view had been expressed by other workers (SILEGHEM et al., 1989; SCHLEIFER and MANSFIELD, 1993). Following the results of their studies, TABEL et al. (2013) concluded that any attempt to produce an effective vaccine should first address the problem of induction of immunosuppression by the trypanosomes.

Continued efforts to develop effective vaccines have resulted in studies of other nonvariable molecules in the trypanosome. African trypanosomes express numerous nonvariable antigens (LUBEGA et al., 2002; RASOOLY and BALABAN, 2004; LI et al., 2009). The flagellar pocket has been of particular interest, as an organelle specialized in endocytosis and exocytosis, containing relatively well-conserved receptors (MKUNZA et 
K. I. Eghianruwa et al.: Chemotherapeutic control of trypanosomosis

- a review of past measures, current status and future trends

al., 1995; FIELD and CARRINGTON, 2009), cytoskeleton proteins (HUTCHINSON et al., 2004) and trypanosomal microtubulin (LUBEGA et al., 2002; LI et al., 2007). RASOOLY and BALABAN (2004) reported 100\% protection from an otherwise lethal challenge of a heterologous strain of T. brucei when they used native or recombinant microtubule-associate protein (MAP p15) as a vaccine in mice. Similarly, LUBEGA et al. (2002), reported 60-80\% protection by renatured T. brucei tubulin against T. brucei, T. congolense or T. rhodesiense challenge in mice, and that four out of five mice, given passive immunity by the transfer of anti-nTbTub serum, were completely protected, while one of the five was partially protected. LI et al., (2007) also reported $83.3 \%, 70 \%$ and $76 \%$ protection by renatured recombinant $\mathrm{T}$. evansi beta-tubulin against strains of T. evansi, T. equiperdum and T. b. brucei, respectively. Serum collected from rabbits immunized with recombinant beta-tubulin inhibited the growth of T. evansi, T. equiperdum and T. b. brucei in vitro (LI et al., 2007).

\section{Conclusion}

If trypanosomosis must be controlled relatively cheaply, vaccination still remains the best theoretical option. This is particularly expedient considering the fact that trypanosomosis affects poor economies and the cost of developing new effective drugs is exorbitant. There is little doubt that the introduction of an effective vaccine, if used strategically, along with improved treatment methods and tsetse control measures, would make an enormous contribution to the control of African trypanosomosis. This would be followed by increased human productivity and livestock production in endemic trypanosome areas of the African continent.

\section{References}

AFEWERK A. Y, A. P. CLAUSEN, B. G. ABEBE, B. G. TILAHUN, D. MEHLITZ (2000): Multiple-drug resistant Trypanosoma congolense populations in village cattle of Metekel district, North-West Ethiopia. Acta. Trop. (Basel). 76, 231-238.

AKANJI, M. A., O. S. ADEYEMI, S. O. OGUNTOYE, F. SULYMAN (2009): Psidium guajava extract reduces trypanosomosis associated lipid peroxidation and raises glutathione concentrations in infected animals. EXCLI J. 8, 148-154.

ALIU, Y. O., C. N. CHINEME (1980): Isometamidium-dextran complex: Toxicity and activity against Trypanosoma vivax and Trypanosoma congolense in rats and mice. Toxicol. Appl. Pharmacol. 53, 196-203.

ALIU, Y. O., M. MAMMAN, A. S. PEREGRINE (1993): Pharmacokinetics of diminazene in female Boran (Bos indicus) cattle. J. Vet. Pharmacol. Ther. 16, 291-300.

ALIU, Y. O., S. ODEGAARD, E. SǿGNEN (1984): Diminazene/Berenil, bioavailability and disposition in dairy goats. Acta Vet. Scand. 5, 593-596.

ALIU, Y. O., S. ǾDEGAARD (1985): Pharmacokinetics of diminazene in sheep. J. Pharmacokinet. Biopharm. 13, 173-184. 
K. I. Eghianruwa et al.: Chemotherapeutic control of trypanosomosis

- a review of past measures, current status and future trends

ALIU, Y. O. A. SANNUSI (1979): Isometamidium-dextran complex: therapeutic activity against Trypanosoma vivax infection in Zebu cattle. J. Vet. Pharmacol. Ther. 2, 265-273.

ALSFORD, S. R. B. CURRIER, J. A. GUERRA-ASSUNÇÃO, T. G. CLARK, D. HORN (2014): Cathepsin-L Can Resist Lysis by Human Serum in Trypanosoma brucei brucei. PLoS Pathog. 10, e1004130.

DOI:10.1371/journal.ppat.1004130

ANENE, B. M., C. A. ROSS, S. M. ANIKA, C. C. CHUKWU (1996): Trypanocidal resistance in Trypanosoma evansi in vitro; effects of verapamil, cyproheptadine, desipramine and chlorpromazine alone and in combination with trypanocides', Vet. Parasitol. 62, 43-50.

ANENE, B. M., S. M. ANIKA, C. C. CHUKWU (1997): Effects of difluoromethylornithine after intravenous administration and its combination with diminazene aceturate against Trypanosoma brucei in experimentally infected dogs in Nigeria. Rev. Elev. Med. Vet. Pays. Trop. 50, 221-225.

ANENE, B. M., C. E. OGBUANYA, E. S. MBAH, R. C. EZEOKONKWO (1999): Preliminary efficacy trial of cymelarsan in dogs and mice artificially infected with Trypanosoma brucei isolated from dogs in Nigeria. Rev. Elev. Med. Vet. Pays. Trop. 52, 123-128.

ANENE, B. M., D. N. ONAH, Y. NAWA (2001): Drug resistance in pathogenic African trypanosomes: what hopes for the future? Vet. Parasitol. 96, 83-100.

ASUZU, I. U., C. N. CHINEME (1990): Effects of Morinda lucida leaf extracts on Trypanosoma brucei brucei infection in mice. J. Ethnopharmacol. 30, 307-313.

BALDISSERA, M. D, R. A. GONÇALVES, M. R. SAGRILLO, T. H. GRANDO, C. S. RITTER, F. S. GROTTO, G. F. BRUM, S. C. Da LUZ, S. O. SILVEIRA, V. P. FAUSTO, A. A. BOLIGON, R. A. VAUCHER, L. M. STEFANI A. S. Da SILVA, C. F. SOUZA, S. G. MONTEIRO (2016a): Effects of treatment with the anti-parasitic drug diminazene aceturate on antioxidant enzymes in rat liver and kidney. Naunyn Schmiedebergs Arch Pharmacol. 389, 429-438.

BALDISSERA, M. D., T. H. GRANDO, C. F. SOUZA, L. F. COSSETIN, M. R. SAGRILLO, K. N. A. P. T. DA SILVA, D. F. D. LANA, A. S. DA SILVA, L. M. STEFANI, S. G. MONTEIRO (2016b): Nerolidol nanospheres increases its trypanocidal efficacy against Trypanosoma evansi: New approach against diminazene aceturate resistance and toxicity. Exp. Parasitol. $166,144-149$.

BARRETT, M. P., W. D. BOYKIN, R. BRUN, R. R. TIDWELL (2007): Human African trypanosomiasis, pharmacological re-engagement with a neglected disease. Br. J. Pharmacol. $152,1155-1171$.

BEIG M, F. OELLIEN, L. GAROFF, S. NOACK, R. L. KRAUTH-SIEGEL, P. M. SELZER (2015): Trypanothione Reductase: A Target Protein for a Combined In Vitro and In Silico Screening Approach. PLoS Negl. Trop. Dis. 9, e0003773.

DOI: 10.1371/journal.pntd.0003773

BELLUTI, F., E. ULIASSI, G. VERONESI, C. BERGAMINI, M. KAISER, R. BRUN, A. VIOLA, R. FATO, P. A. M. MICHELS, R. L. KRAUTH-SIEGEL, A. CAVALLI, M. L. BOLOGNESI (2014) Toward the development of dual-targeted glyceraldehyde-3-phosphate dehydrogenase/

Vet. arhiv 88 (2), 245-270, 2018 
K. I. Eghianruwa et al.: Chemotherapeutic control of trypanosomosis

- a review of past measures, current status and future trends

trypanothione reductase inhibitors against Trypanosoma brucei and Trypanosoma cruzi. ChemMedChem. 9, 371-382.

BRAIDE, V. B., K. I. EGHIANRUWA (1980): Isometamidium residues in goat tissues after parenteral administration. Res. Vet. Sci. 29, 111-113.

BUDD, L. T (1999): DFID-Funded Tsetse and Trypanosomosis Research and Development since 1980, Vol. 2 Economic Analysis. UK Department for International Development, pp 139.

BUDDE, H., L. FLOHÉ (2003): Enzymes of the thiol-dependent hydroperoxide metabolism in pathogens as potential drug targets. BioFactors. 27, 83-92.

CHAU, N. V. V., L. B. CHAU, M. DESQUESNES, N. P. H. LAN, J. I. CAMPEL, N. V. CUONG, B. YIMMING, P. CHALERMWONG, S. JITTAPALAPONG, J. R. FRANCO, N. T. TUE, J. CARRIQUE-MAS, T. P. T. THIANH, N. T. V. THIEU, A. BERTO, N. T. HOA, N. V. M. HOANG, N. C. TU, N. K. CHUYEN, B. WILLS, T. H. HIEN, G. E. THWAITES, S. YACOUB, S. BAKER (2016): A Clinical and Epidemiological Investigation of the First Reported Human Infection With the Zoonotic Parasite Trypanosoma evansi in Southeast Asia. Clin. Infect. Dis. 62, 1002-1008.

CHAUDHURI, M., R. D. OTT, G. C. HILL (2006): Trypanosome alternative oxidase: from molecule to function. Trends Parasitol. 22, 484-491.

DARJI, A., R. LUCAS, S. MAGEZ, E. TORREELE, J. PALACIOS, M. ILEGHEM, S. E. BAJYANA, R. HAMERS, P. DE BAETSELIER (1992): Mechanisms underlying trypanosomeelicited immunosuppression. Ann. Soc. Belg. Med. Trop. 72, Suppl 1, 27-38.

De JONG, W. H., P. J. A. BORM (2008): Drug delivery and nanoparticles: Applications and hazards. Int. J. Nanomedicine 3, 133-149.

DELESPAUX, V., H. P. De KONING (2007): Drugs and drug resistance in African trypanosomiasis. Drug Resist. Updat. 10, 30-50.

DHOLLANDER, S., A. JALLOW, K. MBODGE, S. KORA, M. SANNEH, M. GAYE, J. BOS, S. LEAK, D. BERKVENS, S. GEERTS (2006): Equine trypanosomosis in the Central River Division of the Gambia, a study of veterinary gate-clinic consultation records. Prev. Vet. Med. $75,152-162$.

DREWS, J. (2004): Paul Ehrlich, Magister Mundi, Nature Rev. Drug Discov. 3, 797-801.

EGHIANRUWA, K. I. (2012): Effect of supplemental antioxidants, vitamin C and DMSO on weight gain and survivability in T. brucei infected and diminazene treated rats. Vet. arhiv. 82, 519-529.

EGHIANRUWA, K. I., P. C. G. ODIAKA, J. OGUNPOLU (2004): A preliminary comparative efficacy study of isometamidium following oral and intramuscular administration in mice experimentally infected with T. congolense. Sahel J. Vet. Med. 3, 33-37.

EGHIANRUWA, K. I., S. M. ANIKA (2010) Effects of dimethyl sulphoxide and ascorbic acid pretreatment on prepatent period, parasitemia, hematology and tissue pathology in rats infected with T. brucei. Trop. Vet. 28, 13-20.

EGHIANRUWA, K. I., S. M. ANIKA (2011): Effects of selenium and tocopherol supplementation on the efficacy of diminazene aceturate in reversing T. brucei-induced anemia in rats. Vet. arhiv. 81, 647-656. 
K. I. Eghianruwa et al.: Chemotherapeutic control of trypanosomosis

- a review of past measures, current status and future trends

EGHIANRUWA, K. I., S. M. ANIKA (2012): Effects of DMSO on diminazene efficacy in experimental murine T. brucei infection. Int. J. Ani. Vet. Adv. 4, 93-98.

EGHIANRUWA, K. I., S. M. ANIKA, S. O. AKPAVIE (2009): Efficacy of diminazene with and without ascorbic acid supplementation in T. brucei infected rats. Trop. Vet. 27, 20-36.

EGHIANRUWA, K. I., R. I. OBIDIKE (2011): Effects of antioxidants on the efficacy of diminazene aceturate treatment of experimental murine Trypanosoma congolense infection. Ani. Prod. Res. Adv. 7, 134-140.

ELLIS, J., M. SARKAR, E. HENDRIKS, K. MATTHEWS (2004): A novel ERK-like, CRK-like protein kinase that modulates growth in Trypanosoma brucei via an autoregulatory C-terminal extension. Mol. Microbiol. 53, 1487-1499.

FEVRE, E. M., K. PICOZZI, J. FYFE, C. WAISWA, M. ODIIT, P. G. COLEMAN (2005): A burgeoning epidemic of sleeping sickness in Uganda. Lancet 366, 745-747.

FAYE, D., P. DE ALMEIDA, B. GOOSSENS, S. OSAER, M. NDAO, D. BERKVENS, N. SPEYBROECK, F. NIEBERDING, S. GEERTS (2001): Prevalence and incidence of trypanosomosis in horses and donkeys in the Gambia. Vet. Parasitol. 101, 101-114.

FIELD, M. C., M. CARRINGTON (2009): The trypanosome flagellar pocket. Nature Rev. Microbiol. 7, 775-786.

FLUCK, D. J., J. S. HOPKINS (1988): Chemotherapy and chemoprophylaxis of bovine trypanosomiasis with liposomal trypanocides. International Scientific Council for Trypanosomiasis Research and Control, Proceedings of the Nineteenth Meeting, Lome, 1987, Publication No. 114 OAU/STRC, Nairobi, 302-313.

GEERTS, S., P. H. HOLMES, M. C. EISLER, O. DIALL (2001): African bovine trypanosomiasis, the problem of drug resistance. Trends Parasitol. 17, 25-28.

GILBERT, R. J. (1983): Studies in rabbits on the disposition and trypanocidal activity of the antitrypanosomal drug, diminazene aceturate (Berenil). Br. J. Pharmacol. 80, 133-139.

GRAY, A. R. (1976): Immunological research and the problem of immunization against African trypanosomiasis. Trans. R. Soc. Trop. Med. Hyg. 70, 119-121.

GROOTENHUIS, J. G., R. H. DWINGER, R. B. DOLAN, S. K. MOLOO, M. MURRAY (1990): Susceptibility of African Buffalo and Boran cattle to Trypanosoma congolense transmitted by Glossina morsitans centralis. Vet. Parasitol. 35, 219-231.

GROSSMAN, S. A., S. PHUPHANICH, G. LESSER, J. ROZENTAL, L. B. GROCHOW, J. FISHER, S. PIANTADOSI (2001): Toxicity, Efficacy, and Pharmacology of Suramin in Adults With Recurrent High-Grade Gliomas. J. Clin. Oncol. 19, 3260-3266.

GURIB-FAKIM, A., M. F. MAHOMOODALLY (2013): African flora as potential sources of medicinal plants: towards the chemotherapy of major parasitic and other infectious diseases- A Review. Jordan J. Biol. Sci. 6, 77-84.

GUTIERREZ, C., J. A. CORBERA, K. BAYOU, F. VAN GOOL (2008): Use of cymelarsan in goats chronically infected with Trypanosoma evansi. Ann. NY. Acad. Sci. 1149, 331-333. 
K. I. Eghianruwa et al.: Chemotherapeutic control of trypanosomosis

- a review of past measures, current status and future trends

HAGOS A., B. M. GODDEERIS, K. YILKAL, T. ALEMU, R. FIKRU, H. T. YACOB, G. FESEHA, F. CLAES (2010): Efficacy of Cymelarsan and Diminasan against Trypanosoma equiperdum infections in mice and horses. Vet. Parasitol. 171, 200-206.

HOET, S., F. OPPERDOES, R. BRUN, J. QUETIN-LECLERCQ (2004): Natural products active against African trypanosomes: a step towards new drugs. Nat. Prod. Rep. 21, 353-364.

HUTCHINSON, O. C., H. WEBB, K. PICOZZI, S. WELBURN, M. CARRINGTON (2004): Candidate protein selection for diagnostic markers of African trypanosomiasis. Trends Parasitol. 20, 519-523.

IGBOKWE, I. O., Y. LAFON, I. A. UMAR, L. J. HAMIDU (1998): Erythrocyte and hepatic glutathione concentrations in acute T. brucei infection of rats. Trop. Vet. 16, 81-83.

IHEDIOHA, J. I., A. P. ANWA (2002): Lever retinal and carotenoid concentration of rats experimentally infected with Trypanosoma brucei. Trop. Vet. 20, 1-7.

ILEMOBADE, A. A. (1979): Drug sensitivity of mouse-infected Trypanosoma vivax isolates in cattle and sheep. Proceedings of International Scientific Council for Trypanosomiasis Research and Control (ISCTRC), Yaunde, Cameroon, pp251.

INTERNATIONAL LIVESTOCK RESEARCH INSTITUTE (ILRI) (1996): Annual Report. 18-21.

INTERNATIONAL LIVESTOCK RESEARCH INSTITUTE (ILRI) (1997): Monograph: Disease Resistance and protecting the environment. 10-11.

JAEGER, T., L. FLOHÉ (2006): The thiol-based redox networks of pathogens: Unexploited targets in the search for new drugs. BioFactors. 27, 109-120.

JAMES, D. M (1978): Prophylactic activity in rodents of trypanocides complexed with dextran. Trans. R. Soc. Trop. Med. Hyg. 72, 471-476.

JENNINGS, F. W., D. D. WHITELAW, P. H. HOLMES, H. B. G. CHIZYKA, G. M. URQUHART (1979): The brain as a source of relapsing Trypanosoma brucei in mice after chemotherapy. Int. J. Parasitol. 9, 381-384.

JOSHUA, R. A (1982): Massive increase in splenic germinal centers of chickens experimentally infected with Trypanosoma brucei brucei. Vet. Parasitol. 13, 101-108.

JOSHI, P. P., V. R. SHEGOKAR, R. M. POWAR, S. HERDER, R. KATTI, H. R. SALKAR, H. R (2005): Human trypanosomiasis caused by Trypanosoma evansi in India, the first case report. Am. J. Trop. Med. Hyg. 73, 491-495.

KALIDAS, S., M. PHILLIPS (2012): Identifying new drug targets against African Trypanosomiasis. FASEB J. 26, (No. 1 Supplement) 964.11.

KAGIRA, J. M., N. MAINA (2007): Occurrence of multiple drug resistance in Trypanosoma brucei rhodesiense isolated from sleeping sickness patients. Onderstepoort J. Vet. Res. 74, 17-22.

KELLNER, H-M., H. G. ECKERT, M. H. VOLZ (1985): Studies in cattle of the anti-trypanosomal drug diminazene-aceturate (Berenil). Trop. Med. Parasitol. 36, 199-204.

KIMETO, B.A., G. M. MUGERA, P. N. NYAGA (1990): Haemorrhagic pericarditis in cattle infected with Trypanosoma vivax. Vet. Parasitol. 34, 295-301. 
K. I. Eghianruwa et al.: Chemotherapeutic control of trypanosomosis

- a review of past measures, current status and future trends

KINABO, L. D. B., J. A. BOGAN (1988): The pharmacology of isometamidium. J. vet. Pharmcol. Therap. 11, 233-245.

KRIEGER, S., W. SCHWARZ, M. R. ARIYANAYAGAM, A. H. FAIRLAMB, R. L. KRAUTHSIEGEL, C. CLAYTON (2000): Trypanosomes lacking trypanothione reductase are avirulent and show increased sensitivity to oxidative stress. Mol. Microbiol. 35, 542-552.

KRAUTH-SIEGEL, R. L., H. BAUER, R. H. SCHIRMER (2005): Dithiol proteins as guardians of the intracellular redox milieu in parasites: old and new drug targets in trypanosomes and malaria-causing plasmodia. Angew. Chem. Int. Ed. 44, 690-715.

La GRECA, F., S. MAGEZ (2011): Vaccination against trypanosomiasis: can it be done or is the trypanosome truly the ultimate immune destroyer and escape artist'? Hum. Vacc. 7, 12251233.

LI, S. Q., M. C. FUNG, S. A. REID, N. INOUE, Z. R. LUN (2007): Immunization with recombinant beta-tubulin from Trypanosoma evansi induced protection against T. evansi, T. equiperdum and T. b. brucei infection in mice. Parasite Immunol. 29, 191-199.

LI, S. Q., W. B. YANG, L. J. MA, S. M. XI, Q. L. CHEN, X. W. SONG, J. KANG, L. Z. YANG (2009): Immunization with recombinant actin from Trypanosoma evansi induces protective immunity against T. evansi, T. equiperdum and T. b. brucei infection. Parasitol. Res. 104, 429435.

LINARES, G. E. G., E. L. RAVASCHINO, J. B. RODRIGUEZ (2006). Progresses in the field of drug design to combat tropical protozoan parasitic diseases. Curr. Med. Chem. 13, 335-360.

LOPES, R. A., R. D. RIBEIRO, T. SATAKE, A. NUTI-SOBRINHO, T. A. GARCIA (1990): Trypanosomes of Brazilian fishes, II Trypanosoma barretoi sp. from Hypostomus paulinus (Siluriformes, Loricariidae). Angew Parasitol. 31, 11-14.

LUBEGA, G. W., D. K. BYARUGABA, R. K. PRICHARD (2002): Immunization with a tubulin-rich preparation from Trypanosoma brucei confers broad protection against African trypanosomosis. Exp. Parasitol. 102, 9-22.

LUCKINS, A. G (1992): Trypanosomosis in small ruminants, A major constraint to livestock production? Guest editorial. Br. Vet. J. 148, 471-473.

LUN, Z. R., Z. P. MIN, D. HUANG, J. X. LIANG, X. F. YANG, Y. T. HUANG (1991) Cymelarsan in the treatment of buffaloes naturally infected with Trypanosoma evansi in South China. Acta Trop. 49, 233-236.

MAMMAN, M., Y. O. ALIU, A. S. PEREGRINE, A. S. (1993): Comparative pharmacokinetics of diminazene in noninfected boran (bos indicus) cattle and boran cattle infected with Trypanosoma congolense. Antimicrob. Agents Chemother. 37, 1050-1055.

MANN, A., E. O. OGBADOYI (2012): Evaluation of medicinal plants from Nupeland for their in vivo antitrypanosomal activity. Am. J. Biochem. 2, 1-6.

MANSFIELD, J. M., D. M. PAULNOCK (2005): Regulation of innate and acquired immunity in African trypanosomiasis. Parasite Immunol. 27, 361-371.

MAUDLIN, I. (2006): African trypanosomiasis. Ann. Trop. Med. Parasitol. 100, 679-701.

Vet. arhiv 88 (2), 245-270, 2018 
K. I. Eghianruwa et al.: Chemotherapeutic control of trypanosomosis

- a review of past measures, current status and future trends

MINAGAWA, N., Y. YABU, K. KITA, K. NAGAI, N. OHTA, K. MEGURO, S. SAKAJO, A. YOSHIMOTO (1997): An antibiotic, ascofuranone, specifically inhibits respiration and in vitro growth of long slender bloodstream forms of Trypanosoma brucei brucei. Mol. Biochem. Parasitol. 84, 271-280.

MKUNZA, F., W. M. OLAHO, C. N. POWELL (1995): Partial protection against natural trypanosomiasis after vaccination with a flagellar pocket antigen from Trypanosoma brucei rhodesiense. Vaccine 13, 151-154.

MOHD-SHUKRI, H. B., B. A. H. ZAINAL-ABIDIN (2011): The effects of nerolidol, allicin and berenil on the morphology of Trypanosoma evansi in mice: a comparative study using light and electron microscopic approaches. Malays. Appl. Biol. J. 40, 25-32.

MULUGETA, W., J. WILKES, W. MULATU, P. A. MAJIWA, R. MASAKE, A. S. PEREGRINE (1997): Long-term occurrence of Trypanosoma congolense resistant to diminazene, isometamidium and homidium in cattle at Ghibe, Ethiopia. Acta Trop. 64, 205-217.

MURRAY, M., J. D. BARRY, W. I. MORRISON, R. O. WILLIAMS, H. HIRUMI (1979): A review of the prospects for vaccination in African trypanosomiasis - Part I. World Ani. Rev. 32, 9-13.

MURGOLO, N. J., A. CERAMI, G. B. HENDERSON (1989): Biomedical science and the third world. Under the volcano. Trypanothione reductase. Ann NY Acad Sci. 569, 193-200.

NAKAMURA, K. 1., S. FUJIOKA, S. FUKUMOTO, N. INOUE, K. SAKAMOTO, H. HIRATA, Y. KIDO, Y. YABU, T. SUZUKI, Y. WATANABE, H. SAIMOTO, H. AKIYAMA, K. KITA (2010): Trypanosome alternative oxidase, a potential therapeutic target for sleeping sickness, is conserved among Trypanosoma brucei subspecies. Parasitol. Int. 59, 560-564.

NAULA, C., M. PARSONS, J. C. MOTTRAM (2005): Protein kinases as drug targets in trypanosomes and Leishmania. Biochim. Biophys. Acta 1754, 151-159.

NIHEI, C., Y. FUKAI, K. KITA (2002): Trypanosome alternative oxidase as a target of chemotherapy. Biochim. Biophys. Acta 1587, 234-239.

NJIOKOU, F., C. LAVEISSIERE, G. SIMO, S. NKININ, P. GREBAUT, G. CUNY (2006): Wild fauna as a probable animal reservoir for Trypanosoma brucei gambiense in Cameroon. Infect Genet Evol. 6, 147-153.

NOK, A., S. WILLIAMS, P. ONYENEKWE (1996): Allium sativum-induced death of African trypanosomes. Parasitol. Res. 82, 634-637.

ODIKA, I. E., I. U. ASUZU, S. M. ANIKA (1995): The effects of hyperosmomolar agents, lithium chloride and sucrose on the brain concentration of diminazene aceturate in rats', Acta Trop (Basel). 60, 119-125.

OGUN, O. O., K. I. EGHIANRUWA(1993): A preliminary study of the absorption of isometamidium chloride (Samorin) by the stomach and small intestine of rat. J. Chemother. 5, 107-109.

OMOJA V. U., A. O. ANAGA, I. R. OBIDIKE, T. E. IHEDIOHA, P. U. UMEAKUANA, L. I.. MHOMGA I. U. ASUZU, S. M. ANIKA (2011): The effects of combination of methanolic leaf extract of Azadirachta indica and diminazene diaceturate in the treatment of experimental Trypanosoma brucei brucei infection in rats. Asian Pac. J. Trop. Med. 4, 337-341.

ONAH, D. N. (1991): Porcine trypanosomiasis in Nigeria. Trop. Anim. Health Prod. 23, 141-146. 
K. I. Eghianruwa et al.: Chemotherapeutic control of trypanosomosis

- a review of past measures, current status and future trends

ONYIAH, J. A. (1997): African animal trypanosomiasis, an overview of the current status in Nigeria. Trop. Vet. 15, 111-116.

ONYEYILI, P. A., S. M. ANIKA (1989): The influence of Trypanosoma congolense infection on the disposition kinetics of diminazene aceturate in dog. Vet. Res. Comm. 13, 231-236.

ONYEYILI, P. A., S. M. ANIKA (1991): Diminazene aceturate residues in the tissues of healthy, Trypanosoma congolense and Trypanosoma brucei brucei infected dogs. Br. Vet. J. 147, 155162.

ONYEYILI, P. A., G. O. EGWU, G. I. JIBIKE, N. NZERIBE, S. S. ADAMU (1992): The effects of chloropromazine hydrochloride of tissue distribution of diminazene aceturate in rabbits. Ann. Borno. 9, 227-233.

ONYEYILI, P. A., S. SANI, G. O. EGWU, Q. N. ARUKWE, O. ADEWALE (2002): Effect of water deprivation on the elimination of diminazene aceturate from blood and edible tissues of goats. Pak. J. Biol. Sci. 5, 1000-1003.

OTSULYA, M., K. KAMAR, M. MUTUGI, A. R. NJOGU (1992): Preliminary efficacy trial of Cymelarsan, a novel trypanocide, in camels naturally infected with Trypanosoma evansi in Kenya. Acta Trop. (Basel). 50, 271-273.

PINCHBECK, G. L., L. J. MORRISON, A. TAIT, J. LANGFORD, L. MEEHAN S. JALLOW, J. JALLOW, A. JALLOW, R. M. CHRISTLEY (2008): Trypanosomosis in The Gambia, prevalence in working horses and donkeys detected by whole genome amplification and PCR, and evidence for interactions between trypanosome species. BMC Vet. Res. 4, 7-11.

RAETHER, W., P. HAJDU, H. SEIDENATH, D. DAMM (1974): Pharmacokinetic and chemoprophylactic studies on Berenil in Macaques (Trypanosoma rhodesiense infection). J. Trop. Med. Parasitol. 25, 42-48.

RASOOLY R. 1, N. BALABAN (2004): Trypanosome microtubule-associated protein p15 as a vaccine for the prevention of African sleeping sickness. Vaccine 22, 1007-1015.

RATHORE, S., N. M. ANJOU, K. M. BALVINDER, C. SHALKI (2016): Chemotherapeutic approaches against Trypanosoma evansi: retrospective analysis, current status and future outlook. Curr. Top. Med. Chem. 16, 2316-2327.

REMME, J. H., E. BLAS, L. CHITSUlO, P. M. DESJEUX, H. D. ENGERS, T. P. KANYOK (2002): Strategic emphases for tropical diseases research, a TDR perspective. Trends Parasitol. $18,421-426$.

RUDENKO, G. I. (2011): African trypanosomes: the genome and adaptations for immune evasion. Essays Biochem. 51, 47-62.

RICHARDSON, J. L., I. R. E. NETT, D. C. JONES, M. H. ABDILLE, I. H. GILBERT, A. H. FAIRLAMB (2009): Improved tricyclic inhibitors of trypanothione reductase by screening and chemical synthesis. ChemMedChem. 4, 1333-1340.

ROSS, C. A., A. M. TAYLOR (1990): Trypanosoma congolense, an in vitro assay to distinguish drug-resistant from drug-sensitive populations. Parasitol. Res. 76, 326-331.

SALEM, M. M., K. A. WERBOVETZ (2006): Natural products from plants as drug candidates and lead compounds against leishmaniasis and trypanosomiasis. Curr. Med. Chem. 13, 2571-2598. 
K. I. Eghianruwa et al.: Chemotherapeutic control of trypanosomosis

- a review of past measures, current status and future trends

SAMDI, S. M., A. O. FAJINMI, J. O. KALEJAYE, B. WAYO, M. K. HARUNA, J. E. YARNAP, W. P. MSHELIA, A. O. USMAN, S. M. HAMRA, A. JIJITAR, R. OGUNWOLE, R. P. OVBAGBEDIA R. BIZI (2011): Prevalence of Trypanosomiasis in Cattle at slaughter in Kaduna Central abattoir. Asian J. Anim. Sci. 5, 162-162.

SCHLEIFER, K. W., J. M. MANSFIELD (1993): Suppressor macrophages in African trypanosomiasis inhibit $\mathrm{T}$ cell proliferative responses by nitric oxide and prostaglandins. $\mathrm{J}$. Immunol. 151, 5492-5503.

SEBOLT-LEOPOLD, J. S., R. HERRERA (2004): Targeting the mitogen-activated protein kinase cascade to treat cancer. Nature Rev. Cancer. 4, 937-947.

SHIFERAW, S., Y. MUKTAR, D. BELINA (2015): A review on trypanocidal drug resistance in Ethiopia. J. Parasitol. Vect. Biol. 7, 58-66.

SILEGHEM, M., A. DARJI, L. REMELS, R. HAMERS, P. DE BAETSELIER (1989): Different mechanisms account for the suppression of interleukin 2 production and the suppression of interleukin 2 receptor expression in Trypanosoma brucei-infected mice. Eur. J. Immunol. 19, 119-124.

SINGH, R., J. W. LILLARD (2009). Nanoparticle-based targeted drug delivery. Exp. Mol. Pathol. $86,215-223$.

SIMO, G. A., S. W. NKININ, F. NJIOKOU, S. HERDER (2006): High prevalence of Trypanosoma brucei gambiense group 1 in pigs from the Fontem sleeping sickness focus in Cameroon. Vet. Parasitol. 139, 57-66.

SINGH R, J. W. LILLARD Jr (2009): Nanoparticle-based targeted drug delivery. Exp. Mol. Pathol. $86,215-223$.

SMITH, D. H., J. PEPIN, A. H. STICH (1998): Human African trypanosomiasis, an emerging public health crisis. Br. Med. Bull. 54, 341-355.

SNOW, W. F., T. J. WACHER, P. RAWLINGS (1996): Observations on the prevalence of trypanosomosis in small ruminants, equines and cattle, in relation to tsetse challenge, in The Gambia. Vet. Parasitol. 66, 1-11.

SPATZ, M., A. M. RAP, S. I. RAPOPORT, I. WATZO (1976): Effect of hypertonic solutions and of $\mathrm{HgCl} 2$ on the uptake of $14 \mathrm{c}$ - glucose analogue by rabbit brain', In: Blood, Brain Barrier in Physiology and Medicine. $1^{\text {st }}$ ed. (Rapoport, S. I., Ed.), Haven Press, New York, 185-186.

STEENKAMP, D. J. (2002): Thiol metabolism of the trypanosomatids as potential drug targets. IUBMB Life 53, 243-248.

STRUMBERG, D., S. SEEBER (2005): Raf kinase inhibitors in oncology. Onkologie, 28, 101-107.

STUMP, B., M. KAISER, R. BRUN, R. L. KRAUTH-SIEGEL, F. DIEDERICH (2007): Betraying the parasite's redox system: diaryl sulfide-based inhibitors of trypanothione reductase: subversive substrates and antitrypanosomal properties. ChemMedChem 2, 1708-1712.

SUTHERLAND, I. A, V. CODJIA, S. K. MOLOO, P. H. HOLMES, A. S. PEREGRINE (1992): Therapeutic activity of isometamidium chloride in Boran cattle against a tsetse-transmitted clone of Trypanosoma congolense with a low level of drug resistance. Trop. Anim. Health Prod. 24, 157-163. 
K. I. Eghianruwa et al.: Chemotherapeutic control of trypanosomosis

- a review of past measures, current status and future trends

TABEL, H., G. WEI, M. SHI (2008): T cells and immunopathogenesis of experimental African trypanosomiasis. Immunol. Rev. 225, 128-139.

TABEL, H., G. WEI, H. J. BULL (2013): Immunosuppression: Cause for failures of vaccines against african trypanosomiasis. PLOS Neglected Tropical Diseases. (Raper, J. Ed.), e2090.

DOI: $10.1371 /$ journal.pntd.0002090

TAYLOR, J. E., G. RUDENKO (2006): Switching trypanosome coats: what's in the wardrobe'? Trends Genet. 22, 614-20.

TROUILLER, P. T., P. L. OLLIARO (1999): Drug development output from 1975 to 1996, what proportion for tropical diseases? Int. J. Infect. Dis. 3, 61-63.

TRUC, P., V. JAMONNEAU, P. N'GUESSAN, L. N'DRI, P. B. DIALLO, G. CUNY (1998): Trypanosoma brucei ssp. and T, congolense, mixed human infection in Cote d'Ivoire. Trans $\mathrm{R}$ Soc Trop Med Hyg. 92, 537-538.

UMAR, I. A., Z. A. TOH, F. I. IGBALAJOBI, A. GIDADO, L. B. BURATAI (2000): The role of vitamin $\mathrm{C}$ administration in alleviation of organ damage in rats infected with Trypanosoma brucei. J. Clin. Biochem. Nutr. 28, 1-7.

UNCITI-BROCETA, J. D., J. L. ARIAS, J. MACEIRA, M. SORIANO, M. ORTIZ-GONZÁLEZ, J. HERNÁNDEZ-QUERO, M. MUÑÓZ-TORRES, H. P. DE KONING, S. MAGEZ, J. A. GARCIA-SALCEDOET (2015): Specific Cell Targeting Therapy Bypasses Drug Resistance Mechanisms in African Trypanosomiasis. PLoS Pathog 11, e1004942.

DOI:10.1371/journal.ppat.1004942

VINCENT, O. A., M. K. DANIEL, L. K. MOSES (2008): RNA interference: a pathway to drug target identification and validation in trypanosome. Afr. J. Biochem. Res. 2, 66-73.

WABALE V, P. NALAGE, A. JOSHI, R. BHARADWAJ, K. DESHPANDE, A. CHOWDHARY (2015). Human Asian trypanosomiasis due to Trypanosoma evansi: A rare case. J. Adv. Parasitol. 2, 65-68.

WEI, G., H. BULL, X. ZHOU, H. TABEL (2011): Intradermal infections of mice by low numbers of African Trypanosomes are controlled by innate resistance but enhance susceptibility to reinfection. J. Infect. Dis. 203, 418-429.

WEI, G., H. TABEL (2008): Regulatory T cells prevent control of experimental African trypanosomiasis. J. Immunol. 180, 2514-2521.

WENZLER, T., B. G. SCHUMANN, R. S. SCHMIDT, P. MÄSER A. BERGNER, I. RODITI, R. BRUN (2016): A new approach to chemotherapy: drug-induced differentiation kills African trypanosomes. Sci. Rep. 2.6:22451.

DOI: $10.1038 /$ srep22451

WELLDE, B. T., D. WAEMA, D. A. CHUMO, M. J. REARDON, F. OLOO, A. R. NJOGU, E. A. OPIYO, S. MUGUTU (1989): Review of tsetse control measures taken in the Lambwe Valley in 1980 - 1984. Ann. Trop. Med. Parasitol. 83, Supplement 1, 119-125.

WHITESIDE, E. F. (1962): The control of cattle trypanosomiasis with drugs in Kenya: Methods and costs. East Afr. Agr. J. 28, 6773. 
K. I. Eghianruwa et al.: Chemotherapeutic control of trypanosomosis

- a review of past measures, current status and future trends

WIESE, M., D. KUHN, C. G. GRUNFELDER (2003): Protein kinase involved in flagellar-length control. Eukaryot. Cell 2, 769-777.

YABU, Y., A. YOSHIDA, T. SUZUKI, C. NIHEI, K. KAWAI, N. MINAGAWA, T. HOSOKAWA, K. NAGAI, K. KITA, N. OHTA (2003): The efficacy of ascofuranone in a consecutive treatment on Trypanosoma brucei brucei in mice. Parasitol. Int. 52, 155-164.

YABU, Y., T. SUZUKI, C. NIHEI, N. MINAGAWA, T. HOSOKAWA, K. NAGAI, K. KITA, N. OHTA (2006): Chemotherapeutic efficacy of ascofuranone in Trypanosoma vivax-infected mice without glycerol. Parasitol. Int. 55, 39-43.

YOUSSIF, F. M., O. S. A. MOHAMMED, A. A. GAMEEL, T. HASSAN (2010): Efficacy and toxicity of homidium bromide (ethidium) in goats infected with T. vivax. Small Ruminant Res. 89, 36-41.

YOUSSIF, F. M., O. S. A. MOHAMMED, T. HASSAN (2008): Efficacy and toxicity of cymelarsan ${ }^{\circledR}$ in Nubian goats infected with Trypanosoma evansi. J. Cell Anim. Biol. 2, 140-149.

ZHANG, Z.Q., C. GIROUD, T. BALTZ (1992): In vivo and in vitro sensitivity of Trypanosoma evansi and T. equiperdum to diminizene, suramin, MelCy, quinapyramine, and isometamidium. Acta Trop. (Basel) 50, 101-110.

ZWEYGARTH, E., J. NGERANWA, R. KAMINSKY (1992): Preliminary observations on the efficacy of MelCy (Cymelarsan) in domestic animals infected with stocks of Trypanosoma brucei brucei and T. evansi. Ann. Trop. Med. Parasitol. 43, 226-228.

Received: 15 November 2016

Accepted: 2 May 2017

\section{EGHIANRUWA, K. I., O. A. ORIDUPA: Kontrola tripanosomoze kemoterapeuticima - pregled prošlih mjera, sadašnje stanje i budući trendovi. Vet. arhiv 88, 245-270, 2018.}

\section{SAŽETAK}

Afrička tripanosomoza glavna je nametnička bolest ljudi i životinja na afričkom kontinentu južno od Sahare. Njezini su uzročnici različite vrste tripanosoma koje se prenose na domaćina ubodom zaraženog prijenosnika muhe ce-ce. Napori koji se ulažu u kontroli bolesti uključuju i pokušaje za smanjenje populacije prijenosnika uporabom klopki, primjenom insekticida, postupkom sterilnih mužjaka kao i liječenjem te profilaksom kemoterapeuticima poput izometamidija, homidija, kvinapiramina i diminazena. Ti su lijekovi u uporabi više od pedeset godina i povezani su s teškom toksičnošću organizma i otpornošću parazita. Prijetnja od ove bolesti nije uklonjena unatoč višegodišnjim naporima nekih laboratorija za pronalaženje novih oblika liječenja proučavanjem farmakokinetike tripanocida, zatim kombiniranom terapijom, uporabom medicinskog bilja te primjenom antioksidansa. Ni razvoj učinkovitog cjepiva nije bio uspješan, zbog antigenskih promjena na površinskoj ovojnici tripanosoma. To je smanjilo nade za napredak u razvoju cjepiva, ako ga nije i potpuno zaustavilo. Ipak, najnovija istraživanja pokazuju da bi tripanosomski mikrotubulin mogao biti održiv antigen za razvoj cjepiva. Ovaj je pregledni članak usredotočen na mjere poduzimane za kontrolu tripanosomoze u afričkih životinja kemoterapijom. U njemu se također razmatraju buduće mjere i perspektive s obzirom na to da dosadašnje mjere nisu bile uspješne u kontroli bolesti.

Ključne riječi: kemoterapija; tripanosomoza; mjere kontrole; dvostruko liječenje; kombinirana terapija; ljekovito bilje; antigenska varijacija; antigen tubulin 